Research Article

\title{
EFFECT OF BULB SIZES ON THE SEED YIELD OF TWO ONION (Allium cepa L.) VARIETIES
}

\author{
S. Ahmed ${ }^{1 *}$, M.A. Rahim ${ }^{2}$, M. Moniruzzaman ${ }^{3}$, M.A. Khatun ${ }^{4}$, \\ F.N. Jahan ${ }^{5}$ and R. Akter ${ }^{6}$ \\ ${ }^{1}$ Bangladesh Agricultural University - Germplasm Centre, Mymensingh \\ ${ }^{2}$ Department of Horticulture \\ ${ }^{1}$ Bangladesh Agricultural University, Mymensingh \\ ${ }^{3}$ Senior Scientific Officer, Agricultural Research Station, Bangladesh Agricultural Research \\ Institute, Pahartali, Chittagong \\ ${ }^{4}$ Bangladesh Rural Development Board, Dhaka \\ ${ }^{5}$ SAARC Agriculture Centre, BARC Complex, Farm gate, Dhaka \\ ${ }^{6}$ Regional Horticulture Research Centre, Sibpur, Narsingdi
}

\begin{abstract}
An experiment was carried out at Horticulture Farm of Bangladesh Agricultural University, Mymensingh during the period from October 2018 to March 2019 to examine the effects of different bulb size viz., large size bulb $(15 \pm 1 \mathrm{~g})$, medium size bulb $(10 \pm 1 \mathrm{~g})$, small size bulb $(7 \pm 1 \mathrm{~g})$ on seed production of two onion varieties (Taherpuri and Kalash Nagari). Significant variation observed in both varieties for most of the parameters based on onion bulb size. The variety Kalash Nagari showed better performances compared to variety Taherpuri. After 60 days of planting, Kalash Nagari variety gave the highest plant height $(55.07 \mathrm{~cm})$, number of leaves $(20.62)$, stalk length $(100.78 \mathrm{~cm})$, and total seed yield $\left(630 \mathrm{~kg} \mathrm{ha}^{-1}\right)$, while in Taherpuri plant height, leaf number, stalk length and total seed weight were $32.21 \mathrm{~cm}, 6.93,61.47$ $\mathrm{cm}$ and $270 \mathrm{~kg} \mathrm{ha}^{-1}$, respectively. Large sized bulb gave better performance compared to small sized bulb. The large sized bulb gave highest plant height $(49.83 \mathrm{~cm})$ and highest total seed yield $(490 \mathrm{~kg}$ $\mathrm{ha}^{-1}$ ). Medium size bulb gave the seed yield (460 $\left.\mathrm{kg} \mathrm{ha}^{-1}\right)$ and lowest in small size bulb $\left(390 \mathrm{~kg} \mathrm{ha}^{-1}\right)$. Seed yield was significantly affected by the combined effects of variety and bulb size. Kalash Nagari onion with large sized bulb gave the highest seed yield (660 $\mathrm{kg} \mathrm{ha}^{-1}$ ) and Taherpuri variety with small sized bulb gave the lowest seed yield (180 $\left.\mathrm{kg} \mathrm{ha}^{-1}\right)$.
\end{abstract}

Keywords: Bulb size, Onion, Seed, Variety, Yield

*Corresponding author: shamimbau0091@gmail.com 
Ahmed et al.

\section{INTRODUCTION}

Onion (Allium cepa L.) is one of the most important bulb and major spice crop in Bangladesh. Among all of the spice crops, onion has great significance for their diversified use in our daily life. It is commonly known as "Queen of the kitchen, "due to its highly valued flavor, aroma, and unique taste, and the medicinal properties of its flavor compounds (Selvaraj, 1976; Griffiths et al., 2002). The plant has shallow adventitious fibrous roots (Ranjitkar, 2003). The onion bulb ranges in shape from flat to globular to oblong, and the onions are usually of three colors: red, white, and yellow (Fritsch, 2005).

It is used in the preparation of almost all food of our daily diet. The crop is also appreciated as condiments for flavoring foods. It can be used as a stimulant, promotes the flow of urine, uses against tuberculosis, venereal disease, typhoid fever, chest and lungs problem. The crop is being cultivated all over the world. It is being domesticated for 5000 years or more and is being extensively cultivated throughout the world (Brewster, 1994). The major onion growing countries of the world are India, Pakistan, China, Korea, Netherland, Israel, Japan, Turkey, Syria, Egypt, USA, Lebanon etc. (FAO, 2015). Bulb is the main edible portion of onion. In Bangladesh, onion is mainly produced in winter season. Usually, it is sown in October to November and harvesting is mostly done in the months from February to March. Onion cultivation during kharif season has some limitations due to adverse weather along with the absence of summer tolerant varieties and lack of proper cultural practices. But demand for its use is ever increasing irrespective of season. Onion is not only considered as spice it also used as vegetables. Fructans (polysaccharides) are the principal storage carbohydrates in onions. In a study of 60 vegetables, onions were reported to have the highest quantity of fructans, which have the potential to decrease the population of bacteria (Roberford, 2007).

It belongs to the family Alliaceae. The onion is also known as the bulb onion or common onion, used as a vegetable and is the most widely cultivated species of the genus Allium. This genus also contains several other species variously referred to as onions and cultivated for food, such as the Japanese bunching onion (A. fistulosum), the Egyptian onion (A. proliferum), and the Canada onion (A. canadense). The name "wild onion" is applied to a number of Allium species, but Allium cepa is exclusively known from cultivation and its ancestral wild original form is not known, although escapes from cultivation have become established in some regions. The onion is most frequently a biennial or a perennial plant, but is usually treated as an annual and harvested in its first growing season. The most important character of onion is its flavor, which increase the taste of food and widely used to increases the taste of different types of food and others like gravies, soups, stew stuffing, fried fish, and meat (Rahim, 1992). It is grown in almost all the districts of Bangladesh, but mostly commercially cultivated in greater districts of Faridpur, Rajshahi, Dhaka, Mymensingh, Cumilla, Jashore, Rangpur, Kushtia, Bogra and Pabna (BBS, 2017). 
Among the spices grown in Bangladesh, onion ranks first in respect of area and production. During the year 2017-2018, onion occupied an area of 4,41,105 acres of land in Bangladesh with a total production of 17,37,714 metric tons (BBS, 2018). However, this production does not fulfill the country's demand. Moreover, neither the yield nor the area under onion cultivation has increased in Bangladesh. Onion contains vitamin $\mathrm{B}$ and trace of vitamin $\mathrm{C}$ and also traces of iron and calcium. The outstanding characteristic of onion is its pungency, which is due to a volatile oil known as allyl-propyl-disulphide (Yawalkar, 1985). The great physician Hippocrates suggested onion as a diuretic, laxative, and emmena-gogue. He also used onion for the treatment of pneumonia, and, externally, for healing putrid wounds (Koch and Lawson, 1996). Ascorbic acid is the most abundant vitamin found in the onion bulb, with a concentration of $1 \mathrm{mg} / \mathrm{g}$ dry weight (Breu, 1996). Onion contains steroidal saponins (Carotenuto et al., 1999), which prevent absorption of cholesterol in the intestine.

In Bangladesh, onion is commonly planted with the onset of winter which is short and mild in nature (Rashid, 1976). It is short day favored crop, which condition helps to seed production. The farmers of Bangladesh cannot adopt early planting due to climatic limitations. Early planted onion seed crops are often severely affected by diseases due to late rainfall or floods. High temperature also affects fruit setting and normal development of seed. Onion is cross pollinated in nature and bees, flies and other insects do pollination. It is essential to ensure that there is sufficient population of pollinating insects to achieve the full potential of onion seed. The yield of onion is influenced by many factors, among which cultivars, soil and climate, seedling age, bulb weight, spacing, date of planting and seed quality is very important. The availability of quality seed in the market is very poor. The unavailability of good quality onion seeds is greatly responsible for low yield in Bangladesh (Bokshi et al., 1989). Seed is the basic and essential input for any crop production. According to Thompson (1979), high quality seed is the critical input on which all other inputs will depend for their full effectiveness. However, authorized inputs are very limited and a huge quantity of seed is smuggled in the country from the neighboring countries. This position created some critical situation for onion cultivation in Bangladesh. Under the circumstances, the Government of the People's Republic of Bangladesh has emphasized on "seed development" in the Fifth Five Year Plan (GOB, 1998). Before going for extensive production of seeds, an intensive research is needed to ensure best quality production. Onion is known to be a photo-and thermo-sensitive plant (Jones and Mann, 1963). Due to some environmental limitations (short winter season) the plants raised from seed in most cases do not bear good seed in the same season in Bangladesh (Rashid, 1976; Rahim et al. 1982). Rahim et al. (1982) reported that generally bulb-to-bulb method is appropriate for onion seed production in Bangladesh. However, the limited information was found on different aspects of seed production such as varietal differences and proper size 
of mother bulbs. Therefore, the present study was conducted to investigate the effect of bulb size on seed contributing characters of two onion varieties.

\section{MATERIALS AND METHODS}

\section{Experimental site}

An experiment was carried out to study the effect of bulb size on the seed production of two varieties of onion during the rabi season of 2018-2019. The research work was carried out at the Horticulture Farm, Bangladesh Agricultural University, Mymensingh. The soil of the experimental area was sandy loam type and belonged to the Old Brahmaputra Flood Plain Alluvial Tract (UNDP, 1988). The experimental area is under the sub-tropical climate which is characterized by heavy rainfall, high humidity, high temperature, relatively long day during April to September and scanty rainfall, low humidity, low temperature and short-day period during the rest period of the year.

\section{Plant materials}

In the research work, the bulbs (different size grades) of onion $c v$. "Taherpuri" and "Kalash Nagari" variety were selected and used in this study. This seed bulb was collected from the USDA-ARS Alliums Project Laboratory, Department of Horticulture, BAU, Mymensingh.

\section{Research area preparation and intercultural operation}

The experiment was laid out in a randomized complete block design (RCBD) with three replications. The space between the blocks was $50 \mathrm{~cm}$ length of each plot was $10 \mathrm{~m}$ and width was $1 \mathrm{~m}$. Adequate care and management of the plants under different experiment were taken as per requirement. The plants were properly irrigated, fertilized and for controlling diseases and insects, fungicides and insecticides were applied as when required.

\section{Data observation}

Morphological data such as seed germination, length of stalk, plant height and number of leaves per plant and yield contributing character like flower per umbel, number of fruit set percent, seed yield, seed weight per hill, 1000 seed weight etc. were recorded during study period.

\section{Statistical analysis}

The mean values of all treatments were calculated and the analysis of variance for most of the characters was accomplished by $F$ variance test. The significance of difference among the treatment means was evaluated by least significant difference (LSD) test at $5 \%$ and $1 \%$ levels of probability (Gomez and Gomez, 1984). 


\section{RESULTS AND DISCUSSION}

\section{Bulb sizes effect on growth and seed yield contributing characters}

\section{Plant height and number of leaves per plant}

Bulb size had highly significant effect on plant height and leaves per plant. The largest bulb produced significantly the tallest plant $(49.83 \mathrm{~cm})$ than those of smallest bulb $(43.92 \mathrm{~cm})$ up to 60 DAP. Highly significant difference in the number of leaves per plant in respect of bulb size was recorded. The onion bulbs planted with the large bulb size produced large number of leaves per plant (17.13) at 60 DAP. The lowest number of leaves per plant (7.60) was recorded from the small bulb size at 30 DAP (Table 1).

Table 1. Main effect of bulb size on plant height \&bulb size on number of leaves/ plant at different days after planting of onion

\begin{tabular}{lllllllll}
\hline Bulb size & \multicolumn{3}{l}{$\begin{array}{l}\text { Plant height (cm) at different days after } \\
\text { planting (DAP) }\end{array}$} & \multicolumn{5}{l}{$\begin{array}{l}\text { No. of leaves/plant at different } \\
\text { days after planting (DAP) }\end{array}$} \\
\cline { 2 - 9 } & 30 & 40 & 50 & 60 & 30 & 40 & 50 & 60 \\
\hline $\mathrm{S}_{1}$ & 30.73 & 40.09 & 45.72 & 49.83 & 10.90 & 14.23 & 16.27 & 17.13 \\
$\mathrm{~S}_{2}$ & 29.78 & 38.32 & 42.77 & 46.30 & 9.10 & 11.60 & 13.57 & 14.27 \\
$\mathrm{~S}_{3}$ & 29.22 & 36.93 & 41.52 & 43.92 & 7.60 & 9.33 & 10.97 & 12.17 \\
$\mathrm{LSD}_{0.05}$ & 0.108 & 0.343 & 0.081 & 0.974 & 1.15 & 0.581 & 0.675 & 0.869 \\
LSD $_{0.01}$ & 0.153 & 0.488 & 0.116 & 1.385 & 1.64 & 0.826 & 0.959 & 1.236 \\
$\begin{array}{l}\text { Level of } \\
\text { significance }\end{array}$ & $* *$ & $* *$ & $* *$ & $* *$ & $* *$ & $* *$ & $* *$ & $* *$ \\
\hline
\end{tabular}

** = Significant at $1 \%$ level of probability

$\mathrm{S}_{1}=$ Big size bulb, $\mathrm{S}_{2}=$ Medium size bulb, $\mathrm{S}_{3}=$ Small size bulb

Number of flowers per umbel

No. of flowers per umbel was statistically significant in bulb size. The higher no. of flowers per umbel (301.33) was found in large size bulb and the lower no. of flowers per umbel (212.17) was recorded in small size bulb (Table 2). 
Table 2. Main effect of bulb size on yield and yield contributing characters of onion

\begin{tabular}{ccccccccccc}
\hline $\begin{array}{c}\text { Bulb } \\
\text { size }\end{array}$ & $\begin{array}{c}\text { Seed } \\
\text { germination } \\
(\%)\end{array}$ & $\begin{array}{c}\text { Length } \\
\text { of } \\
\text { stalk } \\
(\mathrm{cm})\end{array}$ & $\begin{array}{c}\text { No. of } \\
\text { flowers } \\
\text { per }\end{array}$ & $\begin{array}{c}\text { No. of } \\
\text { umbel } \\
\text { fruit } \\
\text { per }\end{array}$ & $\begin{array}{c}\text { Fruit } \\
\text { smbel } \\
(\%)\end{array}$ & $\begin{array}{c}\text { No. of } \\
\text { umbel } \\
\text { per } \\
\text { plot }\end{array}$ & $\begin{array}{c}\text { Seed } \\
\text { weight } \\
\text { of } \\
1000 \\
\text { seeds } \\
(\mathrm{g})\end{array}$ & $\begin{array}{c}\text { Seed } \\
\text { weight } \\
\text { her }\end{array}$ & $\begin{array}{c}\text { Seed } \\
\text { weight } \\
\text { per } \\
\text { plot } \\
(\mathrm{g})\end{array}$ & $\begin{array}{c}\text { Seed } \\
\text { weight } \\
\text { hectar } \\
\left(\mathrm{kg} \mathrm{ha}^{-1}\right)\end{array}$ \\
\hline $\mathrm{S}_{1}$ & 81.50 & 85.90 & 301.33 & 152.83 & 57.81 & 46.83 & 3.30 & 2.74 & 50.77 & 490 \\
$\mathrm{~S}_{2}$ & 70.17 & 78.63 & 239.17 & 134.00 & 56.84 & 44.00 & 3.26 & 2.32 & 44.72 & 460 \\
$\mathrm{~S}_{3}$ & 65.33 & 78.83 & 212.17 & 139.50 & 51.84 & 36.33 & 3.22 & 1.85 & 39.90 & 390 \\
\hline $\mathrm{LSD}_{0.05}$ & 0.442 & 2.221 & 2.354 & 4.822 & 0.620 & 1.697 & 0.041 & 0.163 & 1.064 & 0.41 \\
\hline $\mathrm{LSD}_{0.01}$ & 0.628 & 3.159 & 3.349 & 6.858 & 0.881 & 2.413 & 0.058 & 0.231 & 1.513 & 0.58 \\
\hline $\begin{array}{c}\mathrm{Level}^{2} \\
\text { of sign }\end{array}$ & $* *$ & $* *$ & $* *$ & $* *$ & $* *$ & $* *$ & $* *$ & $* *$ & $* *$ & $* *$ \\
\hline
\end{tabular}

$* *$ Significant at $1 \%$ level of probability

$\mathrm{S}_{1}=$ Big size bulb, $\mathrm{S}_{2}=$ Medium size bulb, $\mathrm{S}_{3}=$ Small size bulb

\section{Number of umbels per plot}

Number of umbel per plot was statistically significant in case of bulb size. The highest number of umbel per plot (46.83) was obtained from the large size bulb and the lowest (36.33) was found in the small size bulb (Table 2).

\section{Number of seeded fruits per umbel}

The number of fruits was increased significantly with the increase in bulb size. Large bulb size produced the highest number of fruits (152.83) while the small size bulbs produced the lowest number of fruits (139.50) (Table 2). Some workers reported the similar result (Begum et al., 1998; Muktadir, 2000).

\section{Seed weight per plot}

The difference in seed yield per plot for different bulb sizes was found to be significant. A significant decreasing trend of seed yield per plot was observed with the reduction in bulb size (Table 2). The large sized bulb produced the maximum amount of seed per plot (50.77 g) the lowest amount of seed per plot (39.90 g) was recorded from the small size of bulbs. The results are agreed with others (Pall and Padda, 1972; Rathore, 1980; Verma et al., 1994; Begum et al., 1998; Muktadir, 2000).

\section{Fruit set (\%)}

Bulb Size had significant effects on $\%$ fruit set. The higher $\%$ fruit set $(57.81 \%)$ was recorded in large size bulb late and the lower \% fruit set (51.84) in small size bulb (Table 2). 


\section{Weight of 1000 seeds}

There was no significant influence in respect of weight of 1000 seeds in case of two varieties of onion. The highest weight of 1000 seeds $(3.30 \mathrm{~g})$ was found in the large size bulb and the lowest (3.22 g) was recorded in the small size bulb (Table 2).

\section{Length of stalks}

The effect of bulb size on the stalk length was found to be statistically significant. It was observed that stalk length was highest in large bulb size $(85.90 \mathrm{~cm})$ and stalk length was lowest in small bulb size $(78.83 \mathrm{~cm})$ (Table 2).

\section{Seed weight per hill}

There was a highly significant effect among the three bulb size in respect of seed weight $(\mathrm{g})$ per hill. The highest seed yield per hill $(02.74 \mathrm{~g})$ was obtained from the large sized bulb and the lowest seed yield (1.85 g) was found from the small sized bulb (Table 2). It is observed that small sized bulb gave comparatively lower seed yield per hill.

\section{Seed yield per hectare}

Increase in the size of mother bulbs represented a significant increase in yield per hectare. The highest seed yield $\left(490 \mathrm{~kg} \mathrm{ha}^{-1}\right)$ was found in large size bulb and lowest seed yield (390 kg ha ${ }^{-1}$ ) was found in small size bulb (Table 2). Seed yield per hectare was increased with the increase in bulb size which was also reported by Pall and Padda (1972), Mondal and Choudhury (1980), Rathore (1980), Mollah et al. (1987), Nehra et al. (1988), Ali et al. (1998), Singh and Sachan (1998), Abedin et al. (1999), Muktadir (2000), Muktadir et al. (2001) and Kumar and Singh (2007).

\section{Seed germination percentage}

The germination percentage of harvested seeds varied significantly due to different bulb sizes. Seeds obtained from the largest sized bulb showed the highest $(81.50 \%)$ germination percentage (Table 2). The seeds produced from the small sized bulbs showed the lowest $(65.33 \%)$ germination percentage. The finding of Muktadir (2000) and Muktadir et al. (2001) supported the present result where they showed that higher seed germination percentage was recorded from larger mother bulbs.

\section{Varietal effect on growth and seed yield contributing characters}

\section{Plant height and number of leaves per plant}

There were highly significant variations on varietal differences in respect of plant height and no. of leaves at different days after planting. The variety Kalash Nagari was taller $(55.07 \mathrm{~cm})$ at 60 days after planting (DAP) than the variety Taherpuri $(38.29 \mathrm{~cm})$. The higher number of leaves $(20.62)$ per plant was obtained from the variety Kalash Nagari at 60 DAP while Taherpuri produced the lower (6.93) number of leaves per plant at $30 \mathrm{DAP}$ (Table 3) 
Table 3. Main effect of variety on plant height and number of leaves/plant at different days after planting of onion

\begin{tabular}{|c|c|c|c|c|c|c|c|c|}
\hline \multirow[t]{2}{*}{ Variety } & \multicolumn{4}{|c|}{$\begin{array}{l}\text { Plant height }(\mathrm{cm}) \text { at different days after } \\
\text { planting (DAP) }\end{array}$} & \multicolumn{4}{|c|}{$\begin{array}{l}\text { No. of leaves/plant at different days } \\
\text { after planting (DAP) }\end{array}$} \\
\hline & 30 & 40 & 50 & 60 & 30 & 40 & 50 & 60 \\
\hline \multirow{2}{*}{$\begin{array}{l}\text { Taherpuri } \\
\text { onion } \\
\text { Kalash Nagari } \\
\text { onion }\end{array}$} & 32.21 & 34.91 & 36.97 & 38.29 & 6.93 & 7.60 & 7.98 & 8.42 \\
\hline & 27.60 & 41.98 & 49.70 & 55.07 & 11.47 & 15.84 & 19.22 & 20.62 \\
\hline $\mathrm{LSD}_{0.05}$ & 0.088 & 0.280 & 0.066 & 0.795 & 0.94 & 0.474 & 0.551 & 0.709 \\
\hline $\mathrm{LSD}_{0.01}$ & 0.125 & 0.398 & 0.094 & 1.131 & 1.34 & 0.675 & 0.783 & 1.009 \\
\hline $\begin{array}{l}\text { Level of } \\
\text { significance }\end{array}$ & $* *$ & $* *$ & $* *$ & $* *$ & $* *$ & $* *$ & $* *$ & $* *$ \\
\hline
\end{tabular}

$* *=$ Significant at $1 \%$ level of probability

\section{Number of umbels per plot}

Varieties were significantly influenced on the number of umbels per plot. The higher number of umbels per plot was counted 68.56in the variety Kalash Nagari, where Taherpuri was 16.22 (Table 4).

\section{Number of flowers per umbel}

There was significant influence in respect of number of flowers per umbel between two varieties of onion. The higher number of flowers per umbel (258.33) was found in the variety Taherpuri in comparison to the variety Kalash Nagari (243.44) (Table 4). This result was supported by Mohanty (2000), who studied using some varieties of onion and find the variation in number of flowers per umbel.

Table 4.Main effect of variety on yield and yield contributing characters of onion

\begin{tabular}{|c|c|c|c|c|c|c|c|c|c|c|}
\hline Variety & $\begin{array}{l}\text { Seed } \\
\text { germina } \\
\text { tion }(\%)\end{array}$ & $\begin{array}{l}\text { Length } \\
\text { of stalk } \\
(\mathrm{cm})\end{array}$ & $\begin{array}{l}\text { No. of } \\
\text { flowers } \\
\text { per } \\
\text { umbel }\end{array}$ & $\begin{array}{l}\text { No. of } \\
\text { seeded } \\
\text { fruit } \\
\text { per } \\
\text { umbel }\end{array}$ & $\begin{array}{l}\text { Fruit } \\
\text { set } \\
(\%)\end{array}$ & $\begin{array}{l}\text { No. of } \\
\text { umbel } \\
\text { per } \\
\text { plot }\end{array}$ & $\begin{array}{l}\text { Seed } \\
\text { weight } \\
\text { of } \\
1000 \\
\text { seeds } \\
(\mathrm{g})\end{array}$ & $\begin{array}{l}\text { Seed } \\
\text { weight } \\
\text { per } \\
\text { hill (g) }\end{array}$ & $\begin{array}{l}\text { Seed } \\
\text { weight } \\
\text { per } \\
\text { plot }(g)\end{array}$ & $\begin{array}{l}\text { Seed } \\
\text { weight } \\
\text { per } \\
\text { hectare } \\
\left(\mathrm{kg} \mathrm{ha}^{-}\right. \\
\text {1) }\end{array}$ \\
\hline $\begin{array}{l}\text { Taherpuri } \\
\text { onion }\end{array}$ & 72.11 & 61.47 & 258.33 & 154.56 & 57.98 & 16.22 & 3.37 & 1.81 & 28.00 & 270 \\
\hline $\begin{array}{l}\text { Kalashnagari } \\
\text { onion }\end{array}$ & 72.86 & 100.78 & 243.44 & 129.67 & 53.01 & 68.56 & 3.14 & 2.80 & 62.26 & 630 \\
\hline $\mathrm{LSD}_{0.05}$ & 0.361 & 1.814 & 1.922 & 3.937 & 0.506 & 1.385 & 0.033 & 0.133 & 0.869 & 0.33 \\
\hline $\mathrm{LSD}_{0.01}$ & 0.513 & 2.580 & 2.734 & 5.600 & 0.720 & 1.971 & 0.047 & 0.189 & 1.236 & 0.47 \\
\hline $\begin{array}{l}\text { Level of } \\
\text { significance }\end{array}$ & $* *$ & $* *$ & $* *$ & $* *$ & $* *$ & $* *$ & $* *$ & $* *$ & $* *$ & $* *$ \\
\hline
\end{tabular}

$* *=$ Significant at $1 \%$ level of probability 


\section{Number of seeded fruits per umbel}

Number of seeded fruits per umbel was statistically significant between two varieties of onion. The higher number of seeded fruits per umbel (154.56) was recorded in the variety Taherpuri compared to the variety Kalash Nagari (129.67) (Table 4).

\section{Fruit set (\%)}

Variety had significant effects on $\%$ fruit set. The higher fruit set $(57.98 \%)$ was recorded in Taherpuri variety and the lower fruit set (53.01\%) in Kalash Nagari variety (Table 4).

\section{Seed weight per plot}

Seed yield per plot was also significantly different in two varieties (Table 4). Seed yield per plot was higher (62.26 g) by the variety Kalash Nagari in comparison to the variety Taherpuri ( $28 \mathrm{~g})$.

\section{Seed weight per hill}

There was a highly significant effect between the two varieties of onion in respect of seed weight $(\mathrm{g})$ per hill. The higher seed weight per hill $(2.80 \mathrm{~g})$ was obtained from Kalash Nagari variety and the lower seed weight per hill (1.81 g) was found from Taherpuri variety (Table 4).

\section{Weight of 1000 seeds}

Varieties were no significant effect on the weight of 1000 seeds. The mean weight of 1000 seeds was $(3.37 \mathrm{~g})$ in the variety Taherpuri compared to the variety Kalash Nagari (3.14 g) (Table 4).

\section{Stalk length}

The effect of variety on the stalk length was found to be statistically significant. It was observed that stalk length was highest in Kalash Nagari variety $(100.78 \mathrm{~cm})$ and stalk length was lowest in Taherpuri variety $(61.47 \mathrm{~cm})$ (Table 4).

\section{Seed yield per hectare}

There was highly significant variation in respect of seed yield per hectare $(\mathrm{kg})$ of two varieties of onion. Variety Kalash Nagari gave significantly the higher seed yield per hectare $\left(630 \mathrm{~kg} \mathrm{ha}^{-1}\right)$ in comparison to the variety Taherpuri $\left(270 \mathrm{~kg} \mathrm{ha}^{-1}\right)$ (Table 4). Rahim et al. (1982) also find the similar type of results.

\section{Seed germination $(\%)$}

There were no significant variations between the treatments in respect of germination percentage of harvested seeds. Higher germination percentage $(72.56 \%)$ was recorded in variety Kalash Nagari compared to Taherpuri $(72.11 \%)$ (Table 4). 


\section{Bulb sizes and varietal effect on growth and seed yield contributing characters}

\section{Plant height and number of leaves per plant}

The combined effect between varieties and bulb sizes recorded highly significant variation among treatment combinations in respect of plant height and leaf. Treatment combination of Kalash Nagari with large sized bulb gave the highest plant height $(59.02 \mathrm{~cm})$ followed by the treatment combination of Taherpuri and small size of bulb $(36.50 \mathrm{~cm})$. The maximum number of leaves per plant (24.87) was obtained from Kalash Nagari with large sized bulb. The lowest number of leaves (7.53) was observed from the treatment combination of Taherpuri and small sized bulb (Table 5).

Table 5. Combined effect of variety and bulb size on plant height and leaves plant ${ }^{-1}$ at different days after planting of onion

\begin{tabular}{|c|c|c|c|c|c|c|c|c|}
\hline \multirow{2}{*}{$\begin{array}{l}\text { Treatment } \\
\text { combination }\end{array}$} & \multicolumn{4}{|c|}{$\begin{array}{l}\text { Plant height }(\mathrm{cm}) \text { at different days } \\
\text { after planting (DAP) }\end{array}$} & \multicolumn{4}{|c|}{$\begin{array}{l}\text { No. of leaves/plant at different days } \\
\text { after planting (DAP) }\end{array}$} \\
\hline & 30 & 40 & 50 & 60 & 30 & 40 & 50 & 60 \\
\hline $\mathrm{V}_{1} \mathrm{~S}_{1}$ & 33.19 & 36.64 & 39.40 & 40.63 & 7.73 & 8.40 & 8.73 & 9.40 \\
\hline $\mathrm{V}_{1} \mathrm{~S}_{2}$ & 31.99 & 34.47 & 36.30 & 37.73 & 6.73 & 7.60 & 8.00 & 8.33 \\
\hline $\mathrm{V}_{1} \mathrm{~S}_{3}$ & 31.47 & 33.63 & 35.20 & 36.50 & 6.33 & 6.80 & 7.20 & 7.53 \\
\hline $\mathrm{V}_{2} \mathrm{~S}_{1}$ & 28.28 & 43.53 & 52.03 & 59.02 & 14.07 & 20.07 & 23.80 & 24.87 \\
\hline $\mathrm{V}_{2} \mathrm{~S}_{2}$ & 27.57 & 42.17 & 49.23 & 54.87 & 11.47 & 15.60 & 19.13 & 20.20 \\
\hline $\mathrm{V}_{2} \mathrm{~S}_{3}$ & 26.97 & 40.23 & 47.83 & 51.33 & 8.87 & 11.87 & 14.73 & 16.80 \\
\hline $\mathrm{LSD}_{0.05}$ & 0.152 & 0.485 & 0.115 & 1.377 & 1.63 & 0.822 & 0.954 & 1.228 \\
\hline $\mathrm{LSD}_{0.01}$ & 0.216 & 0.689 & 0.164 & 1.959 & 2.31 & 1.169 & 1.357 & 1.747 \\
\hline $\begin{array}{l}\text { Level of } \\
\text { significance }\end{array}$ & $* *$ & $* *$ & $* *$ & $* *$ & $* *$ & $* *$ & $* *$ & $* *$ \\
\hline
\end{tabular}

$* *$ Significant at $1 \%$ level of probability

$\mathrm{V}_{1}=$ Taherpuri onion, $\mathrm{V}_{2}=$ Kalash Nagari onion

$\mathrm{S}_{1}=$ Big size bulb, $\mathrm{S}_{2}=$ Medium size bulb, $\mathrm{S}_{3}=$ Small size bulb

\section{Number of umbels per plot}

Variety and bulb size had highly significant effects on number of umbel per plot. The higher number of umbel per plot (76.67) was obtained from $\mathrm{V}_{2} \mathrm{~S}_{1}$ and the lower number of umbel per plot (14.67) was found in $\mathrm{V}_{1} \mathrm{~S}_{3}$ treatment combination (Table 6). 
Table 6. Combined effect of variety and bulb size on yield and yield contributing characters of onion

\begin{tabular}{|c|c|c|c|c|c|c|c|c|c|c|}
\hline $\begin{array}{l}\text { Treatment } \\
\text { combination }\end{array}$ & $\begin{array}{c}\text { Seed } \\
\text { germinatio1 } \\
(\%)\end{array}$ & $\begin{array}{l}\text { Length } \\
\text { of stalk } \\
(\mathrm{cm})\end{array}$ & $\begin{array}{c}\text { No. of } \\
\text { flowers } \\
\text { per } \\
\text { umbel }\end{array}$ & $\begin{array}{l}\text { No. of } \\
\text { seeded } \\
\text { fruit per } \\
\text { umbel }\end{array}$ & $\begin{array}{c}\text { Fruit } \\
\text { set } \\
(\%)\end{array}$ & $\begin{array}{c}\text { No.of } \\
\text { umbel } \\
\text { per } \\
\text { plot }\end{array}$ & $\begin{array}{c}\text { Seed } \\
\text { weight } \\
\text { of } 1000 \\
\text { seeds(g) }\end{array}$ & $\begin{array}{l}\text { Seed } \\
\text { weight } \\
\text { per } \\
\text { hill }(\mathrm{g})\end{array}$ & $\begin{array}{c}\text { Seed } \\
\text { weight } \\
\text { per plot } \\
(\mathrm{g})\end{array}$ & $\begin{array}{l}\text { Seed } \\
\text { weight } \\
\text { per } \\
\text { hectare } \\
\mathrm{kg} \mathrm{ha}^{-1}\end{array}$ \\
\hline $\mathrm{V}_{1} \mathrm{~S}_{1}$ & 85.33 & 66.80 & 308.33 & 162.00 & 59.20 & 17.00 & 3.41 & 2.13 & 34.21 & 330 \\
\hline$V_{1} S_{2}$ & 69.33 & 56.60 & 243.33 & 141.33 & 58.75 & 17.00 & 3.37 & 2.01 & 29.03 & 310 \\
\hline $\mathrm{V}_{1} \mathrm{~S}_{3}$ & 61.67 & 61.00 & 223.33 & 160.33 & 55.99 & 14.67 & 3.34 & 1.28 & 20.76 & 180 \\
\hline $\mathrm{V}_{2} \mathrm{~S}_{1}$ & 77.67 & 105.00 & 294.33 & 145.67 & 56.42 & 76.67 & 3.18 & 3.35 & 67.33 & 660 \\
\hline $\mathrm{V}_{2} \mathrm{~S}_{2}$ & 71.00 & 100.67 & 235.00 & 126.67 & 54.93 & 71.00 & 3.15 & 2.63 & 60.42 & 620 \\
\hline $\mathrm{V}_{2} \mathrm{~S}_{3}$ & 69.00 & 96.67 & 201.00 & 116.67 & 47.69 & 58.00 & 3.09 & 2.42 & 59.04 & 600 \\
\hline $\operatorname{LSD}_{0.05}$ & 0.625 & 3.141 & 3.330 & 6.819 & 0.876 & 2.400 & 0.058 & 0.230 & 1.505 & 0.58 \\
\hline $\mathrm{LSD}_{0.01}$ & 0.889 & 4.468 & 4.736 & 9.699 & 1.246 & 3.413 & 0.082 & 0.327 & 2.140 & 0.82 \\
\hline $\begin{array}{l}\text { Level of } \\
\text { ignificance }\end{array}$ & *** & $* *$ & $* *$ & $* *$ & $* *$ & $* *$ & NS & ** & $* *$ & $* *$ \\
\hline
\end{tabular}

$* *$ Significant at $1 \%$ level of probability

$\mathrm{V}_{1}=$ Taherpuri onion, $\mathrm{V}_{2}=$ Kalash Nagari onion

$\mathrm{S}_{1}=$ Big size bulb, $\mathrm{S}_{2}=$ Medium size bulb, $\mathrm{S}_{3}=$ Small size bulb

\section{Number of flowers per umbel}

The maximum number of flowers per umbel (308.33) was produced by the treatment combination of Taherpuri with large sized bulb. The minimum number of flowers per umbel (201.00) was counted from the treatment combination of Kalash Nagari with small sized bulb (Table 6).

\section{Number of seeded fruits per umbel}

A highly significant combined effect was observed between varieties and bulb size in respect to number of seeded fruits per umbel. The highest number of seeded fruits per umbel (162.33) was given by large size bulbs from the variety of Taherpuri and the lowest number of fruits per umbel (116.67) was obtained from the variety Kalash Nagari with small sized bulb (Table 6).

\section{Fruit set (\%)}

Variety and bulb size had significant effects on $\%$ fruit set. The highest $\%$ fruit set $(59.20 \%)$ was recorded in $\mathrm{V}_{1} \mathrm{~S}_{1}$ and the lowest \% fruit set $(47.69 \%)$ in $\mathrm{V}_{2} \mathrm{~S}_{3}$ (Table 6).

\section{Number of umbel per plot}

The highest number of umbel per plot was recorded in $\mathrm{V}_{2} \mathrm{~S}_{1}$ (76.67). Ali et al. (2015) reported that the big bulbs (12 gm) gave larger numbers of umbels per plan. 


\section{Seed weight per plot}

Highly significant effect between variety and bulb size on seed weight per plot was observed. Plants raised from Kalash Nagari with large bulb produced the highest seed weight per plot (67.33 g). The plants raised from Taherpuri having small sized bulbs gave the lowest seed weight per plot (20.76 g) (Table 6).

\section{Seed weight per hill}

There was a highly a significant effect between variety and bulb size in respect of seed weight $(\mathrm{g})$ per hill. The highest seed weight per hill $(3.35 \mathrm{~g})$ was obtained from $\mathrm{V}_{2} \mathrm{~S}_{1}$ and the lowest seed weight per hill (1.28 g) was found from $\mathrm{V}_{1} \mathrm{~S}_{3}$ treatment combination (Table 6).

\section{Stalk length}

Variety and bulb size showed significant interaction effect on stalk length. The highest stalk length $(105.00 \mathrm{~cm})$ was observed in $\mathrm{V}_{2} \mathrm{~S}_{1}$ and the lowest stalk length $(56.60 \mathrm{~cm})$ was recorded in $\mathrm{V}_{1} \mathrm{~S}_{2}$ treatment combination (Table 6).

\section{Seed weight of 1000 seeds}

The highest weight of 1000 seeds (3.41 g) was found in $\mathrm{V}_{1} \mathrm{~S}_{1}$ and the lowest weight of 1000 seeds $\left(3.09 \mathrm{~g}\right.$ ) was recorded in $\mathrm{V}_{2} \mathrm{~S}_{3}$ treatment combination (Table 6).

\section{Seed weight per hectare}

The interaction and combined effect of variety and bulb size was recorded to be highly significant on seed yield. The highest seed yield $\left(660 \mathrm{~kg} \mathrm{ha}^{-1}\right)$ was found in $\mathrm{V}_{2} \mathrm{~S}_{1}$ and the lowest seed yield $\left(180 \mathrm{~kg} \mathrm{ha}^{-1}\right.$ ) was recorded from $\mathrm{V}_{1} \mathrm{~S}_{3}$ (Table 6).

\section{Seed germination percentage}

The effect had showed a range of variation from $61.67 \%$ to $85.33 \%$ (Table 6). The highest germination $(85.33 \%)$ was recorded with the seeds produced from Taherpuri with large size bulbs. The lowest germination $(61.67 \%)$ was noticed from Taherpuri with small sized bulb. Seed germination was significantly affected by the combined effect of variety and bulb size.

\section{CONCLUSION}

Kalash Nagari variety with big size bulb $(15 \pm 1 \mathrm{~g})$ found to be superior in most of the sensory evaluation parameters like seed yield $\left(660 \mathrm{~kg} \mathrm{ha}^{-1}\right)$. Intensive research is imminent for justifying those sensory characteristics of the onion samples with the application of advanced tools.

\section{REFERENCES}

Abedin, M.J., Rahim, M.A., Islam, K.S. and Haider, M.A. (1999). Effect of planting date and bulb size on the yield and quantity of onion seed. Bangladesh Journal of Seed Science and Technology, 3(1-2):25-28. 
Ali, M.A., Hossain, M.M., Zakaria, M., Naznin, A. and Islam, M.M. (2015). Effect of bulb size on quality seed production of onion in Bangladesh. International Journal of Agronomy and Agricultural Research, 6(4):174-180.

Ali, N., Baloch, M.A., Hussain, S.A. and Ali, N. (1998). Study on the effects of planting space and bulb size on seed production in onion crop. Sharhad Journal of Agriculture, 14(6):563-468.

BBS (Bangladesh Bureau of Statistics). (2017). Statistical Year Book of Bangladesh. Twenty third editions. Statistics and Informatics Division, Ministry of Planning, Government of the People's Republic of Bangladesh. Pp. 142.

BBS (Bangladesh Bureau of Statistics). (2018). Statistical Year Book of Bangladesh. Twenty third editions. Statistics and Informatics Division, Ministry of Planning, Government of the People's Republic of Bangladesh.

Begum, A., Rahim, M.A. and Haider, M.A. (1998). Effect of set size and spacing on the seed production of onion. Bangladesh Journal of Seed Science and Technology, 2(1-2):91-100.

Bokshi, A.I., Mondal, M.F. and Paramanik, M.H.R. (1989). Effect of nitrogen and phosphorous nutrition on the yield and quality of onion seeds. Bangladesh Horticulture, 12(2):30-35.

Breu, W. (1996). Allium cepa L. (onion): Part 1. Chemistry and analysis. Phytomedicine, 3(3):293-306.

Brewester, J.L. (1994). Onion and other vegetable Alliums. CAB International, UK. Pp.236.

Carotenuto, A., Fattorusso, E., Lanzotti, V. and Magno, S. (1999). Spirostanol saponins of Allium porrum L. Phytochemistry, 51(8):1077-1082.

FAO. (2015). Food and Agricultural Organization Quarterly Bulletin of Statistics, Rome, Italy, 10:91-94.

Fritsch, R.M. (2005). Herkunft, taxonomie und geschichte vonAllium. In: Zwiebelanbau, Handbuchfür Praxisund Wissenschaft, Pp. 15-37.

GOB. (1998). The Fifth Five Years Plan, 1997-2002. Planning Commission, Ministry of Planning, Government of the People's Republic of Bangladesh, Dhaka. Pp. 228-244.

Gomez, K.A. and Gomez, A.A. (1984). Statistical Procedure for Agricultural Research. ( $2^{\text {nd }}$ Edition). John Willey and Sons, New York. Pp. 28-192.

Griffiths, G., Trueman, L., Crowther, T., Thomas, B. and Smith, B. (2002). Onions: a global benefit to health. Phytotherapy Research, 16(7):603-615.

Jones, H.A. and Mann, L.K. (1963).Onion and their Allies Leonard Hill (Book) Ltd., London. Pp. 169. 
Koch, H.P. and Lawson, L.D. (1996). Garlic: The Science and Therapeutic Application of Allium sativum L. and Related Species, 2nd edn. Williams \& Wilkins: Baltimore, Maryland.

Kumar, M.S. and Singh, R.B. (2007). Effect of bulb size, varieties and spacing on the growth and seed yield of onion (Allium cepa L.). Progressive Agriculture, 7(1-2):99-101.

Mohanty, B.K. (2000). Screening of common onion varieties for seed production. Journal of Maharashtra Agricultural University. 25(3): 271-273.

Mollah, M.K.U., Quader, M.A. and Ali, M. (1987). Effect of bulb size on seed production of two onion cultivars. Bangladesh Horticulture, 15:18-29.

Mondal, M.F. and Choudhury, M.S.H. (1980). Effect of size of mother bulb on seed yield of onion. Bangladesh Horticulture, 8:21-23.

Muktadir, M.S. (2000). Effect of planting time, bulb size and vernalization on the yield and quality of onion seed. MS Thesis, Department of Horticulture, BAU, Mymeningh. Pp. 124.

Muktadir, M.S., Farooque, A.M., Rahim, M.A. and Hossain, M.M. (2001). Yield and quality of onion seed as influenced by the planting time and bulb size. Bangladesh Journal of Seed Science and Technology, 5(1-2):47-52.

Nehra, B.K., Pandita, M.L. and Singh, K. (1988). Effect of bulb size on onion seed production. Haryana Journal of Horticultural Science, 17(1-2):106-110.

Pall, R. and Padda, D.S. (1972). Effect of nitrogen and plant spacing and size of mother bulb on growth and yield of seed crop of onion. Indian Journal of Horticulture, 29:185-189.

Rahim, M.A. (1992). Spices and plantation crops in National Economic. Proceeding of the sixth National Horticultural Convention and Symposium, held at Bangladesh Agricultural University, Mymensingh during 16-17 April 1992. Pp. 24-29.

Rahim, M.A., Hussain, A. and Siddique, M.A. (1982). Seed production of three onion cultivar. Bangladesh Horticulture, 10(1):31-38.

Rashid, M.M. (1976). Bangladesher Shabji (in Bengali) (First Edition). Bangla Academy, Dhaka, Bangladesh. Pp. 452-457.

Rathore, S.V.S., Verma, J.P. and Kashyap, V.S. (1980). Effect of size of bulb and planting distance on the performance of seed crop of onion. Bangladesh Horticulture, 8:17-21

Roberford, M.B. (2007). Inulin-type fructans: functional food ingredients. The Journal of Nutrition. 137(11):2493S-2502S.

Selvaraj, S. (1976). Onion: queen of the kitchen. Kisan World, 3(12):32-34.

Singh, S.R. and Sachan, B.P. (1998). Response of different bulb sizes and varieties of onion. Crop Research Hisser, 15(1):57-60. 
Thompson, J.R. (1979). An introduction to seed technology. Leonard Hill Books Limited, London. Pp.19.

UNDP. (1988). Land resource appraisal of Bangladesh for agricultural development report 2. Agro-ecological region of Bangladesh. FAO, Rome, Italy. Pp. 577.

Verma, T.S., Chand, R., Thakur, P.C., Lalkhanpan, K.D. and Singh, A. (1994). Effect of bulb size and plant spacing on yield of onion. Indian Journal of Hill Farming,7(1):102-104.

Yawalkar, K.S. (1985). Vegetables crops of India. Agriculture-Horticultural Publishing House, Nagpur. Pp. 288-304. 